\title{
徳川光图『鎌倉日記』にみる近世鎌倉の観光および景観資源の発掘に関する研究
}

\section{A Study on the Grasp of Resources about Tourism and Landscape from "Kamakura Nikki" by TOKUGAWA Mitsukuni}

押田 佳子*

Keiko OSHIDA

\begin{abstract}
Kamakura Nikki", a book of a journey on springs of Kamakura" was the travel literature of early modern Kamakura by TOKUGAWA Mitsukuni. They surveyed around all Kamakura about history and architectures, nature, culture, ruins of the Medieval Period of Kamakura, and the like. Then, Mitsukuni and his research companions found resources: tourism resources, landscape resources involve green. Tourism resources are 173 spots in all composition from hearing research and reading research from classical literature as "Azumakagami". Many of them were temples or shrines, others were occupied historic sites, road, tree, and so on. Mitsukuni and his follows were detected landscape resources as effective tools to gain view area and spatial recognition. Green resources were not recognized regional landscape resources but landmarks as spatial perceptions or holy space as "Chinju". Moreover, they surveyed some scene or sequence, and then traditional noted place were put on recorded for coming generations. Conclusion, they led that the symbolic landscape of Kamakura was landform of "yato".
\end{abstract}

Keywords: Kamakura, tourism resource, landscape resource, KAMAKURA Nikki, TOKUGAWA Mitsukuni, Edo Era キーワード：鎌倉，観光資源，景観資源，鎌倉日記，徳川光图，近世

\section{1. はじめに}

古都『鎌倉』は, 年間 1900 万人の観光客数を誇るわが国を代表 する観光都市である ${ }^{1)}$ 。この鎌倉観光の歴史は古く，江戸時代 (以 降，近世と表す）にまで遡る。

江戸幕府が出来て間もない寛永10（1633）年に五山巡りのため に鎌倉を訪れた沢庵和尚の『鎌倉順礼記』によると，鎌倉五山第 一位の建長寺に関して「人住まざれば夜は獣のすみかと見えたり

(略) 尊像もいまは露しづくに潤ふ。後門の方をみれば唐様に刻 みなしたる曲几，くずれ埋づみてあれども，誰収むる人もなし」 と記しており，当時の鎌倉が荒廃していた様子が窥える ${ }^{2)}$ 。

このような鎌倉を観光都市に発展させるきっかけとなったのは, 徳川幕府が五街道をはじめとする交通網を整備したことに加え，

貞享2（1685）年に徳川光圆監修のもと編纂された『新編鎌倉志』 3)が果たした役割が大きいといわれている。『新編鎌倉志』は，徳 川光㝑 (以下, 光完) が歴史書『大日本史』を制作寸るにあたり， 歴史資料が著しく少ない鎌倉地域を補填するために編纂されたも のであり, 鎌倉の建築や自然, 歴史といった名所旧跡などに加え, 他の見どころや特産物などについても掲載している3)。この情報 量の多さゆえ，『江の島』44゙と後世に執筆された紀行文にも数多 く引用されていることから，近世観光の旅行者たちにガイドブッ クとして携行されていた様子が窅える。

『新編鎌倉志』の刊行に先立ち，延宝2（1674）年に光图自ら現 地調査を実施した調査報告書が『鎌倉日記』であり，一行が実際 に訪れた順に紀行文風にまとめられている゙5)。記述より，光图は 武家政治の根源をな寸中世鎌倉の史料調査に熱心であり，調査の 対象は歴史的な出来事に留まらず，その背景となった山河など地 域資源に及んでいる。このような光图の取り組みは，中世以降に 継承された鎌倉の観光資源の発掘作業といえ，ここで発掘された 資源の多くは現代観光においても重要な意味をもつと考えられる。 以上より，『鎌倉日記』は「鎌倉観光発見」に関わる過程において 重要な文献であると捉える事ができる。そこで本稿では, 『鎌倉日
記』に着目し，その記述より，徳川光图が鎌倉において見出した ことは，現代における観光や景観資源として役立つかどうかを考 察することを目的とする。

\section{2. 研究の位置づけ}

近世鎌倉観光に関する既往研究についてみると，鎌倉観光最盛 期に著名な戯作家・十返舎一九が記した『金草鞋（かねのわらじ） 箱根山七温泉江ノ島鎌倉廻』に着目し，観光経路上で一九が用い た景観鑑賞の技法等を検証した研究6) や複数の紀行文より鎌倉観 光を網羅的に捉えた研究7) がある。これらの研究で扱われた文献 資料の筆者の多くは徳川光图が監修した『新編鎌倉志』を携行し ており，この基礎調査資料にあたる『鎌倉日記』から当時の観光 資源や景観資源を読夕取ることは鎌倉の原風景を理解寸ることに つながり，今後京都や鎌倉などの伝統的な観光地における景観の 保全や継承を踏まえた観光都市計画への展開が期待される。

以上の考えを踏まえ，本稿では文献資料より観光都市鎌倉の発 見のプロセスを捉えることで，鎌倉が本来持つ観光ポテンシャル を見直すことにつながり，地域らしさを活かした観光まちづくり に寄与することをねらいとしている。

\section{3. 鎌倉の定義}

近世の「鎌倉」は領主による封建制度のもと，相模国鎌倉郡と して成立していた。この「郡」も領主の交代などによって幾度か 領地を改変されている。本研究で対象とする「鎌倉」の範囲は, 押田ら の7における定義に従い，近世以降常に「鎌倉」であり続 けた地域である，「六浦 (現横浜市金沢区)」「固瀬河 (現藤沢市)」

「小监 (現逗子市)」「小袋坂 (現鎌倉市)」を東西南北の境界とし た（図-2の白色で示した領域）。

4. 徳川光完『鎌倉日記』における調査の概要 ${ }^{8)}$ 9)

徳川光圆が延宝2 (1974) 年に鎌倉の史跡を巡検した際の紀行文

*日本大学理工学部 


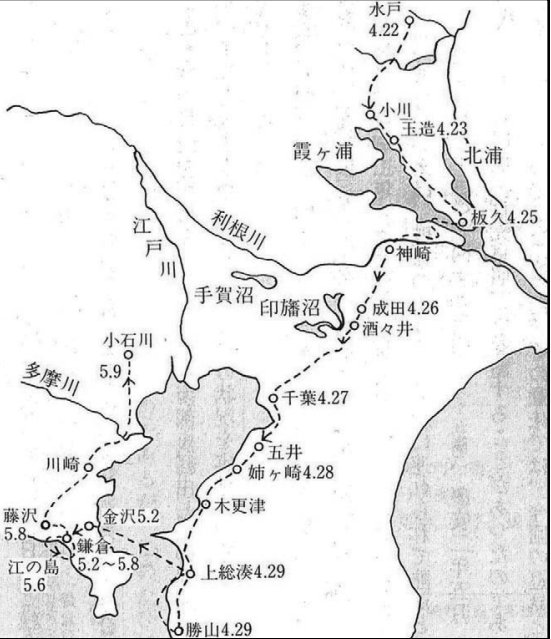

図-1『鎌倉日記』の足跡（延宝 2 年 4 月 22 日 5 月 9 日）

(鈴木瑛一 (2006)「德川光图」 ${ }^{8)}, p p 126$ より転載)

であり，実際には家臣の吉弘元常らが筆を執ったものといわれて いる。光图が歴史書『大日本史』編纂という大事業に取り掛かる にあたり，中世鎌倉に関しては歴史資料がほとんど存在しない状 態であった。そのため, 武家政治の根源をな寸鎌倉幕府時代の研 究を余儀なくされ，延宝元（1673）年の帰府（自分の藩から江戸 の藩屋敷に戻る旅）に際し藩内巡検を行った後に藩領南部から上 総国を経て，上総湊からの船旅て鎌倉へ赴くに至った。

図-1 より，一行は鎌倉に延宝 2 年の 5 月 2〜8 日までの 7 日間 滞在した後江戸に戻っており，この巡検は光图の生涯唯一の旅と されている。『鎌倉日記』は, 『新編鎌倉志』編纂の予行といえる ものであるが，『日記』で指摘しながら『鎌倉志』で言及してい
表－2 『鎌倉日記』掲載地点の分類（数字の単位は地点）

\begin{tabular}{|l|r||l|r|}
\hline \multicolumn{1}{|c|}{ 分類 } & 地点数 & \multicolumn{1}{c|}{ 分類 } & 地点数 \\
\hline 社寺 & 63 & |II & 3 \\
旧跡 & 38 & 切通 & 3 \\
谷 & 13 & 地蔵 & 2 \\
地名 & 11 & 石塔 & 2 \\
坂·道 & 8 & 石·岩窟 & 2 \\
山 & 8 & 樹木 & 1 \\
橋 & 6 & 池 & 1 \\
海岸 & 5 & 潼 & \multicolumn{1}{|c|}{ 合計 } \\
井戸 & 4 & \multicolumn{2}{|c|}{} \\
\hline
\end{tabular}

ない事項もあり, 現地における生情報として貴重な記述も数多 くみられる。これは巻末に「凡ソ此等ノ事, 郷導ノ教二任セ，見 聞ニシタカヒテ草々シク書トメヌ」と記しているように, 『日記』 の記述方針が僧侶など現地の案内人の説明による所が多いからで あろう。また，この調査において『東鑑』や『太平記』など 32 文 献 ${ }^{10)}$ もの参考文献が引用されていることも特徵として挙げられる。 なお，上記の手法で取りまとめられた『鎌倉日記』には，一行 が辿った名所・旧跡順にいわれや名物, 社寺の場合は宝物などの 記載だけでなく，日記以外の記録・鐘銘などを別紙に写したもの や地図もあったとされているが，その所在は不明とされている9 。

\section{5. 観光資源の発掘}

『鎌倉日記』に掲載された調査対象およびその状況を表-1 に示 す。表-1 より, 対象地内で掲載された観光対象は全 173 地点であ り，これらを 5 月 2 日〜 7 日の 6 日間で巡っていた。この期間に 光图一行は, 5 日が最多の 61 地点 (うち鶴岡八幡宮は再訪問), 次いで 6 日が 47 地点, 3 日が 25 地点， 7 日が 24 地点， 2 日が 11 地点と鎌倉内を精力的に巡っており, 雨天で足止めされた 5 月 4 日のみ 6 地点に留まっていた。

表一1 『鎌倉日記』における調査対象およびその状況（数字は『鎌倉日記』内の掲載順序を示す。）

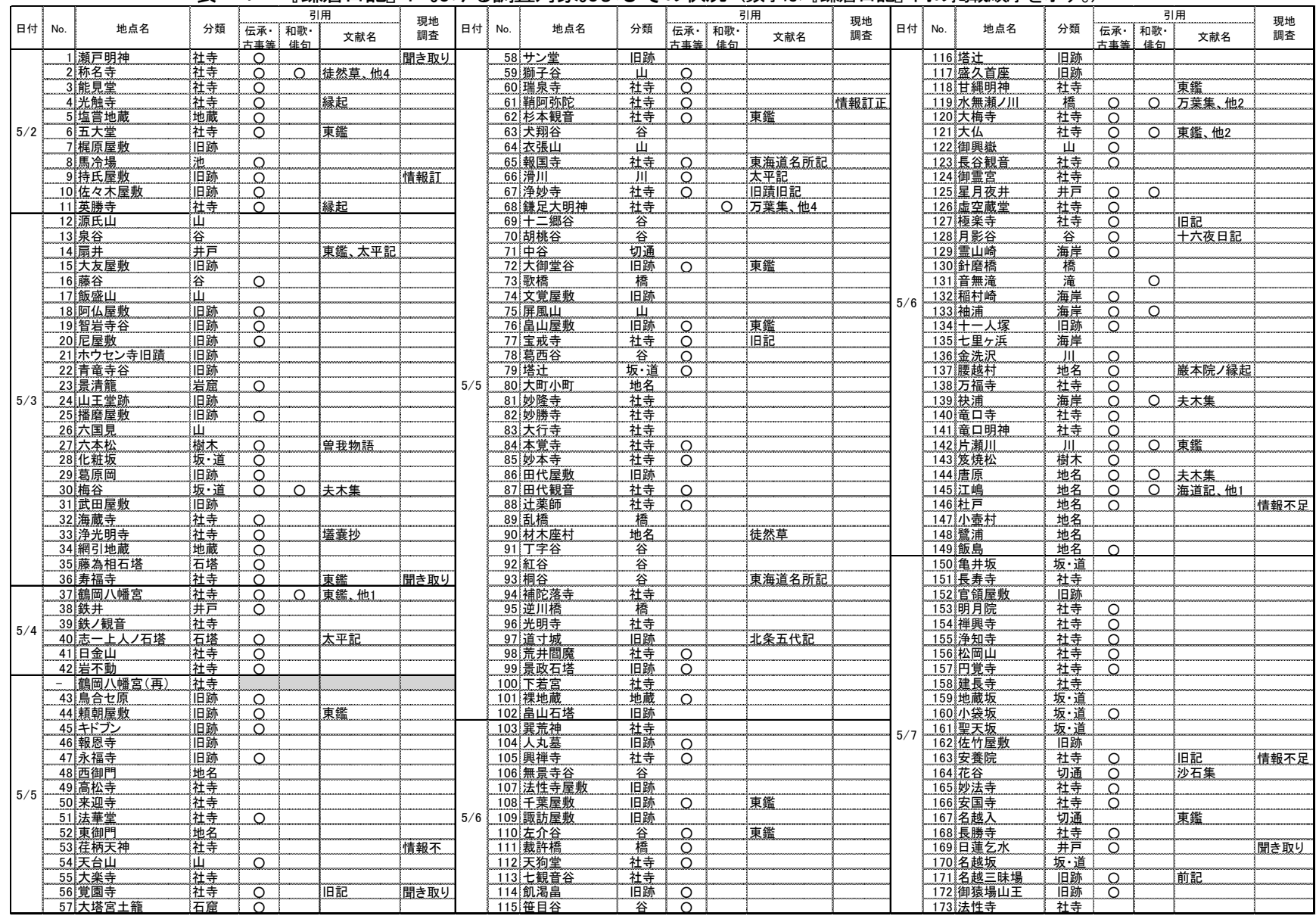


表-2 に鎌倉の観光対象の分類を示す。表-1 に掲載寸る地点名を 現在の観光地や地名を参照し, 社寺, 旧跡, 地名などに 17 分類し た。その結果, 社寺が 63 地点と最も多く, 次いで旧跡が 38 地点 であった。このうち旧跡の多くは，「86 田代屋敷」の「田代ノ観 音ノ北ノ前ナル畠也。と記述されるように, 荒地の状態で発見さ れており, 中世以降廃れたまま放置されている状態が垣間見えた。 また, 谷が 13 地点と 3 番目に多くみられたことについては, 鎌倉 が谷戸地形を有する独特の地形が反映されているといえる。

表-1 より, 調査状況に着目すると, 各観光対象に関寸る伝承・ 古事の記載は「1 瀬戸明神」をはじめ 104 地点でみられ，全体の 約 6 割を占めていた。新古今集等などからの和歌・俳句の引用は 13 地点, 引用文献名を記したものは40 地点であった。中でも『東 鑑』は「5.五大堂」など 12 地点の説明で引用されており，中世武 士の歴史を読み解く上で大変重宝されていたことが窥える。

基本的に全ての地点に対し文献資料に基づく現地調査がなされ ているが，「9 持氏屋敷」と「61 鞩阿弥陀」では文献の情報に誤り があったため記述を訂正しており，「1 瀬戸明神」や「36.寿福寺」 など 4 地点，住職や地元住民への聞き取りを行い，さらなる情報 収集を行っていた。このように各地点で綿密な調査が実施された 一方で，「53 荏柄天神」の「然ドモ祝融ノ災度々ニシテ記録伝八 ラズ。文献徴トスベキナシト云。」にあるように，情報不足である ものも3地点みられた。

また,「158 建長寺」は「五山ノ第一」,「153明月院」は「十刹 ノ第一」，「68.鎌足大明神」は「鎌倉谷七郷，鎌倉七口」と説明が なされており, 新旧の定数名所についても簡単に記載されていた。 特に鎌倉五山 ${ }^{11)}$ についてはその由来故，寺宝を隈なく調査してい るが，表-1 の「158 建長寺」に「昔ノ跡トテ今モ猶実二五山ト才 ボシキハ円覚・建長ノ二寺ノミ。とあり, 必ずしも良好な状態で 維持されていなかったことが捉えられる。

以上のように，『鎌倉日記』に掲載された調查対象地の多くは, 社寺や旧跡が多くを占めていたことが明らかとなった。当時の鎌 倉は，建長寺や荏柄天神の記述にみられるように，由緒ある社寺 においてすら幕府崩壊後の鎌倉は廃れるがまま荒地の状態であっ たことより，中世から近世に至る約 300 年の時間経過ならびに資 料不足は，光图の調査を難航させたと考えられる。

一方で，文献と現地踏査によるきめ細かな調査により，位置関 係やいわれは概ね解明されただけでなく，多くが現代においても 観光地として継承されていることより，光图一行の調査は，現代 観光における発掘作業として位置づけられるといえよう。

\section{6. 景観資源の発掘}

光图一行は現代にとっては観光資源になるものを短期間で多数 抽出するにあたり, 効率的な移動を余儀なくされたと考えられる。 そのため, 巡検の過程において観光対象にかかわる景観や周辺緑 地は空間認識のために必要不可欠なものであったと考えられる。
上記の考えのもと，『鎌倉日記』における景観観賞に関する記載 を表-3，緑地に関する記述を表-4に示し，以下で考察する。

\section{（1）景観観賞の場の発掘}

表-3 より景観観賞に関する記載は 11 地点で 14 件みられ，これ らは視点場と視対象との関係などから，山なみを見渡寸「眺望景 観」が 4 件，山頂より鎌倉の街なみを見下ろす「俯瞰景観」が 2 件，海面とそれに付随寸る景観を愛でる「海岸景観」が 6 件，寺 社の庭園を讃える「庭園景観」が 2 件，が抽出された。

図-2に示すように景観観賞に関寸る記載の多くは「37. 鶴岡八 幡宮」付近の高台に集中しており, 眺望景観または俯瞰景観に適 した立地であることが捉えられる。

分類ごとの傾向をみると, 眺望景観は, 「3.能見堂」の「此地ヨ リ上下総，房州，天神山，鋸山等海上ノ遠近ノ境地」のように高 所から遠方の山並みを捉えた物と，「145.江嶋」の「其上二座して 四方を眺望するに」のように，低地から水平に遠方を捉えたもの とがみられた。特に,「3.能見堂」は「絶景也卜云。」とあるよう に，絶好の視点場であったことが捉えられる。

俯瞰景観は，視点場が高台にあったと考えられるが，「72 大御 堂谷」の「鎌倉中ノ勝地习見, 御所ノ南ノ山ノ麓二勝タル地形ア リ。」にあるように, 鎌倉の中心地を眺める程度の高さであったと 考えられる。

海岸景観のうち 3 件は「145 江嶋」に関連しており，トッテガ 崎や高級宿屋である岩本院を視点場とし, 「士峯ノ雪䇥习照シ, 海 波录漫トシテ無限風光ナリ。」にみられる, 海面とその後背との関 係を愛でている様子が捉えられた。また，「146杜戸」においても，

「(南の海上の名嶋を望み) 折シモ夕陽波二浮ンデ日ヨ洗フガ如 シ。」とあり，殊更波の移ろいが好まれていた様子が捉えられた。

庭園景観は, 「158 建長寺」の「昔ノ跡卜テ今モ猶実二五山トオ ボシキ八円覚・建長ノ二寺ノミ。境内広ク, 山潤林岡樹木秕々夕 ル勝地」にみられるように, 調查時に庭園が良好な状態で維持さ れていた庭園に限られていたことが捉えられた。

以上のように, 光图一行は視点場と視対象との関係に応じて, 景観観賞の場における景観を堪能していた様子が捉えられ，特に

$\lceil 145$ 江嶋」は島内の様々な場所が視点場となる可能性を示唆し たといえる。視対象についても，遠方への眺望，鎌倉全体への眺 望と様々なスケールを扱っており，一方が道中において鎌倉の地 形を理解しながら発掘していったと考えられる。

\section{（2）緑地景観資源の発掘}

表-4より緑地に関する記載は 23 地点で 29 件みられ，これらは 単木 20 件, 森林 9 件に分類される。

分類別に傾向をみると, 単木はマツが 12 件と圧倒的に多く, 他 はイブキ (文中ではビヤクシンと表記) が 3 件, イチョウ, スギ, クスノキ, サクラ, カエデ， ウメがそれぞれ 1 件であった。単木 の多くは，「1.瀬戸明神」の「社ノ左二大ナ古木の柏槙アリ。里民 蛇柏槙卜云。金沢八木ノ一也。」や「3.能見堂」の「堂ノ前二筆捨

表－3 景観観賞の場に関する記載状況（数字は表-1に対応する。）

\begin{tabular}{|c|c|c|c|c|}
\hline & No. & 地点名 & 種類 & 景観 \\
\hline \multirow{4}{*}{ 眺望景観 } & & 能貝堂 & 社寺 & 此地ヨリ上下総、房州、天神山、鋸山等海上ノ遠近ノ境地、(略)絶景也卜云。 \\
\hline & 26 & 六国見 & 山 & 従是安房·上総·下総·武蔵·相模·伊豆ノ六ヶ国能ク見ユル。 \\
\hline & 71 & 中谷 & 切通 & 釈迦堂谷卜モ云フ。雪下ヘ帰ル海道ヨリ名越口ア眺望ス。 \\
\hline & 145 & 江嶋 & 地名 & (魚板岩にて)其上二座して四方を眺望するに(略)、豆駿。 \\
\hline \multirow{2}{*}{ 俯瞰景観 } & 27 & 六本松 & 樹木 & 駿河次郎清重ガ此所ニノボリ、鎌倉中ラ見タル旧跡也トゾ \\
\hline & 72 & 大御堂谷 & 旧跡 & 鎌倉中ノ勝地ヨ見、御所ノ南ノ山ノ麓二勝タル地形アリ。 \\
\hline \multirow{6}{*}{ 海岸景観 } & 97 & 道寸城 & 旧跡 & 此所ヨリ飯嶋ナドヨ望ミテ由比浜习帰ル。 \\
\hline & 145 & 江嶋 & 地名 & (トッテガ崎より)豆州ノ大嶋等見ユル。城ガ嶋ノ北二見タルハ見崎、其北习荒崎ト云。 \\
\hline & 145 & 江嶋 & 地名 & (瘯本院より)士峯ノ雪䇥ヨ照シ、海波沝漫トシテ無限風光ナリ。 \\
\hline & 145 & 江嶋 & 地名 & (厳本院より)多景ニヒカレ、シバシバ盃习傾ク。 \\
\hline & 146 & 杜戸 & 地名 & (南の海上の名嶋を望み)折シモタ陽波二浮ンデ日ヨ洗フガ如シ。 \\
\hline & 148 & 䉆浦 & 地名 & 片浜二テ景地ナリ。 - 一 \\
\hline \multirow[b]{2}{*}{ 庭園景観 } & 153 & 明月院 & 社寺 & 庭除ノ風景殊二勝レタリ。 \\
\hline & 158 & 建長寺 & 社寺 & 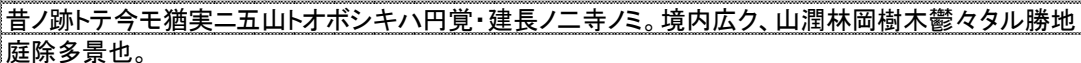 \\
\hline
\end{tabular}




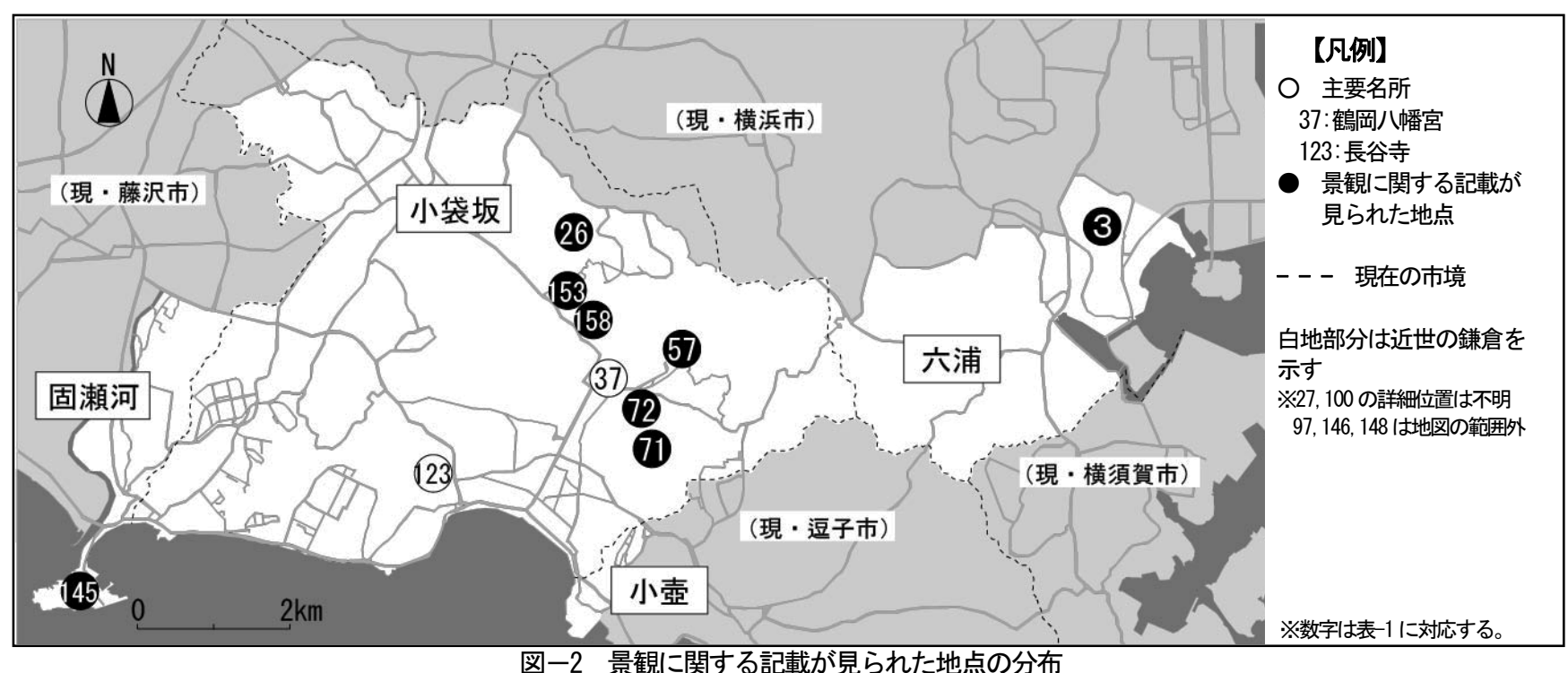

図ー2 景観に関する記載が見られた地点の分布

表一4 緑地に関する記載状況（数字は表-1に対応する）

\begin{tabular}{|c|c|c|c|c|}
\hline & & 地点名 & 種 & 緑地に関する記述 \\
\hline \multirow{19}{*}{$\begin{array}{l}\text { 単 } \\
\text { 木 }\end{array}$} & & 瀬戸明神 & イブキ & $\begin{array}{l}\text { 社ノ左二大ナ古木の柏槙アリ。 } \\
\text { 里民蛇柏槙卜云。金沢ノノ一也。 } \\
\text { (略)此辺二柏植ノ大樹多シ。 }\end{array}$ \\
\hline & & 称名寺 & 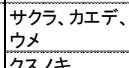 & 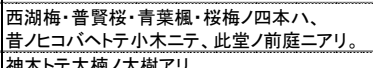 \\
\hline & & & マツ & 堂ノ前二筆捨松卜云一株有り。 \\
\hline & & 肽克虽 & マツ & 邓三本アル松ヨ夫婦松卜云。 \\
\hline & 27 & 空本松 & マッ & 六国見ノ西二ニ本アル松ヨ云。 \\
\hline & & & マツ & 神宮寺人前二松一本有。 \\
\hline & 37 & 鶴岡八幡宮 & 1Fヨ' & 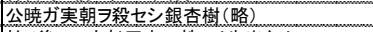 \\
\hline & & & $\pi \neq$ & 社ノ後口二大杉五本一株ヨリ生出多。 \\
\hline & 64 & 衣張山 & マッ & $\begin{array}{l}\text { 彼比所二比丘尼寺アリシニ } \\
\text { (中略)今上ノ山二松ノ大木ニ本アルラ云卜也。 }\end{array}$ \\
\hline & 78 & 葛西谷 & マツ & 上ル山ニ琴引松ト云アリ。 \\
\hline & 89 & 乱橋 & 不明 & 橋ノ西二連理ノ木アリ。 \\
\hline & 121 & 大仏 & マツ & 大仏ヨリ右ノ方二盛久ガ松トテ磯ニアリ。 \\
\hline & 127 & 極楽寺 & マッ & 入口二弁慶ガ腰かケ松アリ。 \\
\hline & 137 & 䁏越村 & マッ & 海中へ指出タル松アリ。 \\
\hline & 138 & 万福寺 & マッ & 弁慶申状引書テ(略)池升二松アリト云。 \\
\hline & 146 & 杜戸 & 1プキ & 社ノ北二飛栢植卜云樹アリ。 \\
\hline & & & マツ & 社ノ西二千貫松、同ク南二腰懸松卜テ (略) \\
\hline & 158 & 建長寺 & $177 \neq$ & 開山黨 前二全利樹ト云木アリ(略) \\
\hline & 173 & 法性寺 & マッ & 其上ニシルシノ朴テ大ナル松アリ。 \\
\hline \multirow{9}{*}{ 森 } & 35 & 藤為相石塔 & - & 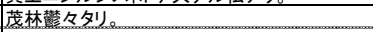 \\
\hline & 68 & 鎌足大明神 & $=$ & 西ノ前に林アリ。即于浄妙寺ノ鎮守トナシテ (略) \\
\hline & 74 & 文賞屋謷 & $\pi \neq 7$ & 杉林アリ \\
\hline & 103 & 巽荒神 & $\pi \neq 7$ & 杉森人内人黨习云。 \\
\hline & 110 & 左介谷 & マツ & 西方岡辺儿松森八(略) \\
\hline & 118 & 縄明神 & $=$ & 海道ノ北二重森アル所也。 \\
\hline & & & & (鐘榕が)高い林ノ中二慈りタリ \\
\hline & 157 & 円賞寺 & - & 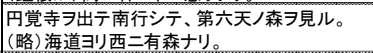 \\
\hline & 172 & 御猿場山王 & マツ & 小山二松少シ有所ク云。 \\
\hline
\end{tabular}

松卜云一株有リ。」のように固有名詞で記載され，地域や社寺を代 表する緑地景観資源として位置付けられたといえる。一方, 「27 六本松」の「六国見八西二二本アル松习云。」にみられるように, 単木はランドマークの役割も果たしていたと考えられ，全体的に 成長が早く樹形がまっすぐな針葉樹が認識されやすかったことが 窺える。森林では，「74 文覚屋敷」の「杉森アリ。」のように樹種 が明らかにされているものはスギ，マツの純林に留まっており， 他は「118 甘縄明神」の「海道ノ北二重森アル所也。のように社 寺などを含む樹木の集団として認識されていた様子が捉えられた。

また, 「68 鎌足大明神」には「西ノ岡に林アリ。即千浄妙寺ノ 鎮守トナシテ」と記載されており，浄明寺全体が「鎮守の森」と してすでに認識されていたことが捉えられた。

以上のように，緑地景観資源は御神木や路傍樹のような地域資 源としてだけでなく, 空間認識のためのランドマーク, または「鎮 守」の表現にあるように社寺を含む神聖な空間として認識されて いたため, 光图たちによって発掘される結果となったとみられる。

\section{7. おわりに}

本研究では, 徳川光圀によって編纂された調査報告書かつ紀行 文の『鎌倉日記』からの読み取りより，鎌倉の景観といえるもの
や観光資源になるものを把握できた。

景観は対象そのものの美しさよりも，視点場と視対象との関係 より捉えた眺望領域を記載する傾向が捉えられた。また，緑地景 観資源は御神木や路傍樹のような地域景観資源としてだけでなく， 空間認識のためのランドマーク，または「鎮守」の表現にあるよ うに社寺を含む神聖な空間として認識されており，このような一 行が現地の捉え方が結果として後世の観光対象における発掘へと 繋がったとみられる。

光图らが発掘した観光資源のうち，社寺に関連する項目や海岸 眺望については，光图以降の著名人などの手を経て，現代の鎌倉 においても継承されており，現代の鎌倉観光に大いに貢献してい るといえる。これは, 鎌倉幕府崩壊後 300 年余りに及ぶ歴史的空 白から, 観光および景観資源を発掘した光图らの成果といえ, 今 後も貴重な地域資源として継承されることであろう。

謝辞 : 本研究の資料とりまとめに際し, 日本大学理工学研究科 不動産科学専攻の瀬畑尚紘氏にご協力いただきました。この場を お借りして，厚く御礼申し上げます。

\section{補注及び引用文献}

1）鎌倉市観光課 : 平成 22 年入込観光客数 : 鎌倉市ホームページ

<http://www.city.kamakura.kanagawa.jp/kisya/data/2011/20110511.html> 2011.5.11 更新，2011.9.2 参照

2) 沢庵宋彭 (1633) : 鎌倉順礼記, 鎌倉市史近世近代紀行地誌編, 吉川弘文館, 5-24pp

3）鈴木一夫 (1990) : 水戸黄門紀行 : 保育社, $11-12 \mathrm{pp}$

4）大島完来 (1805) : 江の島, 鎌倉市史近世近代紀行地誌編, 吉川弘文館, 271-278pp

5）徳川光图 (1674) : 鎌倉日記, 鎌倉市史近世近代紀行地誌編, 吉川弘文館, 28-105pp

6）押田佳子・横内憲久・岡田智秀（2010）: 十返舎一九「金草鞋を通じてみた」近世 鎌倉観光における通過地点の景観構成とその観賞形態に関寸る研究, ランドスケープ 研究73 (5), 519-522 pp

7）押田佳子・横内憲久・岡田智秀・瀬畑尚紘 (2011) : 紀行文より捉えた近世鎌倉に おける観光経路および带在拠点の成立過程に関寸る研究, ランドスケープ研究 74 (5), 431-436 pp

8）鈴木瑛一 (2006) : 徳川光图, 吉川弘文館，123-131 pp

9）鈴木棠三（1976）：鎌倉古絵図・紀行一鎌倉紀行編，東京美術，121-124 pp

10）万葉集，類聚和妙鈔，詞林采葉，東鑑，太平記，徒然草，野槌，長明海道記，発 心集, 沙石州, 続古今和歌集, 新拾遺倭謌集, 夫木集, 類聚名所和歌, 鶴岡記, 鎌倉 五山記，鎌倉物語，鎌倉順礼記，鎌倉記，鎌倉集書，鎌倉覚書，関東兵乱記，寺社領 員数記, 大友興廃記, 王代一覧, 日本事跡考, 神社考, 壒囊鈔, 節用集, 闇斎遠遊紀 行, 道春丙辰紀行, 東海道名所記の計 32 文献を指寸。

11）鎌倉五山とは, 建長寺, 円覚寺, 寿福寺, 浄智寺, 浄妙寺の五寺を指寸。 